\title{
High-tension choices: An analysis of everyday energy-related practices among Lyon-based families
}

\author{
Nathalie Ortar ${ }^{1, \mathrm{a}}$ and Félicie Drouilleau ${ }^{2}$ \\ ${ }^{1}$ LET, ENTPE, rue Maurice Audin, 69518 Vaulx-en-Velin Cedex, France \\ ${ }^{2}$ LISST-Centre d'Anthropologie Sociale, Université Toulouse II - Le Mirail, Maison de la Recherche 5, \\ allées Antonio-Machado, 31058 Toulouse Cedex 9, France
}

\begin{abstract}
This article examines how personal habits related to energy consumption both in a domestic setting and during day-to-day transport use are initially acquired and how they subsequently develop; it also focuses on the nature of the changes that have occurred since the latest jump in energy prices. The analysis presented here draws on the findings of the socio-anthropological component of the TransEnergy research project, financed by the Agence Nationale de la Recherche as part of the Villes Durables (Sustainable Cities) programme, which examined the impact of energy price rises on households living and working in the peri-urban fringe zone of France's second city, Lyon.
\end{abstract}

\section{Introduction}

This article examines how personal habits related to energy consumption both in a domestic setting and during day-to-day transport use are initially acquired and how they subsequently develop; it also focuses on the nature of the changes that have occurred since the latest jump in energy prices. The analysis presented here draws on the findings of the socio-anthropological component of the TransEnergy research project, financed by the Agence Nationale de la Recherche as part of the Villes Durables (Sustainable Cities) programme, which examined the impact of energy price rises on households living and working in the peri-urban fringe zone of France's second city, Lyon. This research focused on two areas: firstly, the extent to which socio-economic factors influences energy consumption and, secondly, how awareness of energy consumption changes according to an individual's stage of life. It thus feeds into a more comprehensive socio-anthropological account of behaviours relating to energy consumption and the processes of change at work in this area. For while, as Isabelle Garabuau-Moussaoui has remarked, "energy is a resource that has, since the end of the $19^{\text {th }}$ century, been perceived as both abundant and a basic necessity" [1], a notion that the use of nuclear power has helped perpetuate in France, this perception of energy as an abundant and cheap resource has nonetheless begun to change in recent years. The rise in energy prices, set against a background of economic crisis and higher living costs, has done much to bring about this shift.

\footnotetext{
ae-mail: nathalie.ortar@entpe.fr
}

This is an Open Access article distributed under the terms of the Creative Commons Attribution License 4.0, which permits unrestricted use, distribution, and reproduction in any medium, provided the original work is properly cited. 
The parallel analysis of "energy consumption associated with being "indoors" and "outdoors", in other words associated with housing and practices of mobility" carried out by Xavier Desjardins and Lucile Mettelal [2] has demonstrated the importance of this relationship to the ways in which periurban residents relate to their lived spaces: the central position of the house for these residents allows certain carry-forward mechanisms applied in the context of energy spending to be understood. We have decided to draw on their approach in our study, which widens the scope of this investigation and adopts a systematic methodological framework allowing energy use in the domestic and transport sectors to be examined in tandem. This project thus integrates an analysis of spending on transport and housing with a wider examination of the overall cost of energy and of consumption more generally, its aim being to establish how attitudes to energy-related spending change over an individual's lifetime and whether or not phenomena of carrying forward and compensation occur between different areas of spending.

The survey was given to employees of companies identified as producing high levels of $\mathrm{CO}_{2}$ by the statistical study (see the article by Patricia Lejoux in this dossier) and consisted of a questionnaire. The companies in question are all situated within the city's commuter belt in zones with poor or non-existent public transport links. Interviewees were selected on the basis of their socio-professional category - office and blue-collar workers were given priority - and of the distance between their home and place of work (equal to or greater than $25 \mathrm{~km}$ (15 miles) or involving a journey of at least 25 minutes each way). 27 individuals from the Lyon area were interviewed. The survey was carried out either in the home, at the place of work (office, meeting room, cafeteria), or in a neutral space. 21 interviewees used a car as their sole means of transport to get to work. The others used public transport or cycled (in one case) for a journey of around one hour each way.

Those surveyed live both in peri-urban zones and within the conurbation. Peri-urbanisation has been associated in many studies with the "middle classes" [3]. However, recent studies based on qualitative research in this area [4], along with statistical analyses of rural and peri-urban populations, have built up a more nuanced picture, emphasising the strong presence of the socio-professional categories represented by blue-collar and office workers [5] who together form what A. Bihr and R. Pfefferkorn have termed a "stable, salaried working class" [6]. We chose to focus our survey on these population segments because they are likely to be particularly vulnerable in the short term owing to the upward trend in the prices of energy and of everyday consumer products. ${ }^{b}$ Indeed, Jean-Pierre Nicolas et al. [7] have demonstrated the increasing vulnerability of people on low and middle incomes living in the peri-urban zones around Lyon. Their comments on this vulnerability chiefly concern the budgetary efforts required to offset increased spending on transport, as living on the outer edges of the conurbation or in Lyon's peri-urban zone usually involves a "high rate of car use and particularly high mileage being driven daily" [8]. In addition to this, "the mobility practices of households identified as being vulnerable are particularly dependent on cars. Before the recent rise in petrol prices they were already spending close to $10 \%$ of their income on their day-to-day transport needs" [9]. However, while families may often move away from the city centre, jobs have also become less geographically concentrated as companies relocate towards the periphery (see Lejoux), as "in the contemporary city, jobs and housing are increasingly dispersed, all the more so in the case of low-skilled jobs and workers" [10]. These relocation zones are in most cases very poorly served by public transport, so reaching them involves, de facto, the use of a car. The present research was carried out within these zones where access to work is difficult. In order to test the hypothesis that stress is being placed on households due to the location of their place of work as well as where they live, employees living in the city centre were also surveyed.

\footnotetext{
b In France, energy precarity is considered to begin when the proportion of the household budget spent on energy reaches $10 \%$. According to the ADEME (Agency for Energy Management and the Environment) (2008), "The poorest households spend 15\% of their income on energy-related expenditure as coompared to $6 \%$ for the wealthiest" (see ADEME \& Vous, Stratégie et Études $\mathrm{n}^{\circ} 3,03 / 04 / 2008$ ); families are classed as being in energy poverty when their expenditure rises above $15 \%$.
} 


\section{Learning energy-management skills}

Energy management involves a complex array of instrumental activities, self-representations and collective performances that cannot be reduced to questions of individual rationality and choice. In her analysis of daily energy consumption, Elizabeth Shove [11] refers in particular to two concepts, comfort and convenience, which she sees as the drivers of consumption. Comfort is a normatised concept that has evolved over time according both to arbitrary regulations and the practical character of its use by the individual, a mode of practice that is in turn dependent on context.

Individual consumption is thus determined by choices made at an international and subsequently a governmental level, then by collective choices over which the individual has little control, such as the type of heating system used in an apartment building, before coming down to an individual level, which itself depends not only on the availability of a choice of technical solutions - whether in terms of insulation, vehicles or electrical goods - but also on collective and family-based norms [12].

Understanding how habits are acquired and built into the full range of daily routines is essential if we are to analyse the origins of the learning process relative to energy management, as well as ongoing processes and the role of public policy in influencing the decisions taken by households. The rather ambivalent status of energy management in western societies is also important in this respect.

Two periods in individuals' lives exert a key influence over how they learn to manage energy. The first occurs in the context of socialisation within the family, whereas the second involves learning through experience after leaving the parental home. As Isabelle Garabuau-Moussaoui et al. [13] have shown, this socialisation within the family occurs on various levels according to the situation in question and the roles being performed. The degree of care taken in relation to consumption thus drops when children are asked to wash, for instance, or when parents resort to using electronic games to keep them quiet. The handing down of ecologically sound actions and attitudes is only partially due to environmentalist discourse, as economic concerns relating to reduced consumption play an important role, as does a more general dislike of waste. A careful attitude towards energy is a constant which cuts across social and political space, even if the desire for economy is as much a part of a wider set of practices (associated principally with the lower classes) targeting all types of waste as it is part of an ecological effort more typical of social milieux whose members have been through higher education [14]. This is shown by a comparison of the attitudes of the parents of Emmanuelle (24, technician, single), who were conscious of environmental issues: "My father would always say: in the winter, when you're in the house, you wear a pullover. [... . My parents are very conscious of environmental issues. Sometimes they can come across as a bit, you could say, like eco-warriors! So that rubbed off on me, too", with those of the mother of Hubert (46, manager, married, 2 children), who was concerned with saving money: "I was brought up like that. Out of a need to save money. But it was ... it wasn't about saving on energy, it was about saving on my mother's purse".

So, in spite of their sometimes ambivalent attitudes and motivations, parents play a fundamental role in inculcating the everyday actions and habits that relate to energy consumption. Passing down a legacy of energy-efficient behaviour is seen as a duty to the next generation, as Gérard (45, divorced, technician, 2 children) reflects: "Our parents taught us to be economical, to keep an eye on energy use. So we do keep an eye on it; and we carry on doing so and we pass it on. Yes, of course, it's a way of life. It's part of our way of life."

Routines may be classed as everyday rituals facilitating action, which itself consists of intentionally chosen activities, the objectives of which, along with their "way of doing things", the individual in question is able to explain. The intentionality behind this internalization relates in particular to a need to reduce uncertainty during the decision-making process [15], and to structure everyday existence [16]. Routines function as bodily memories. Their disadvantage, however, is that they thus limit action [17] as changing them requires effort. In our interviews, it was the routines surrounding the use of water and the reflex actions acquired with respect to electricity, such as turning out the lights when leaving a 
room, that were spontaneously mentioned. These concerns end up becoming partially diconnected from questions of cost, and having more to do with a rejection of all forms of waste.

\subsection{Moving into adulthood}

The experience of studying and/or living away from home for the first time constitutes an intense period of learning which significantly influences future energy consumption behaviours. Unlike in childhood, when learning consisted in following an example and involved a degree of duress, moving out of the parental home is a period of experimentation. Time spent studying at university constitutes a particularly important stage in the development of an awareness of environmental issues, whether or not the studies in question relate specifically to this subject, and this is especially true for individuals belonging to those generations who were less exposed to notions of sustainable development through the primary- and secondary-school curriculum of the time [18]. Even those interviewees who refer to the handing-down of a concern for energy from their parents are quick to point out that the development of their personal awareness of this issue was linked to their studies. Nicolas (27, manager, living with a partner) "My course had an environmental element, so through my studies I became aware of various aspects of my energy consumption. And my parents had done a bit to raise my awareness as well. My course reinforced my consciousness of this issue and my desire to do something positive.” J.-P. Bozonnet [19] has shown that the development of an ecological consciousness in a social context through contact with peers and teachers is closely linked to the subsequent integration and transmission of this consciousness to the following generation. University studies are thus a key period for the socially-determined development of an awareness of energy consumption.

Living away from home for the first time also brings with it a realisation of how much energyrelated costs contribute to the price of accommodation when these costs are borne individually. Even when young people do keep up practices inherited from their parents in terms of cooking and/or energy consumption [20], having to deal with their first fuel bills creates an awareness of energy consumption and heating methods that may not have been present before. Independent living forces one to reconsider practices which had previously been given little or no thought, such as whether or not to heat bedrooms or lower the thermostat. In a home setting, these are usually parental decisions, and it is rare for children to be involved in taking them [21].

Sensations of warmth and cold, along with dryness and dampness, are typically associated with different types of housing and heating systems. These notions derive from childhood memories and early experiences of living away from home which bring greater awareness both of different heat sources and of the varying quality of buildings. The degree of attention paid to energy consumption rests on a foundation of experiences and knowledge accumulated over the years which is called upon when the time comes to move to new accommodation, as Sébastien (42, supervisor, married, 2 children) relates: "We always had apartments with electric heaters when we were students and it always made the winters unbearable. We tried just leaving the heating off completely but, whew! ... Sometimes it was just, you know, horrible. And then there are... we had books going mouldy because we left the heating off, we never opened the windows... so,you know, whew!... we had mezzanines to try to sleep as high up as possible and keep as warm as possible. But then when you had to climb down, it was just the pits. [...] So that's why we're... [...] we're trying to find a compromise."

\subsection{Evolution of energy-awareness over accommodation trajectories}

We will classify the memory of these sensations, along with the habits picked up in different types of accommodation, as habitational experiences which will determine subsequent housing choices by focusing the individual's attention on one particular type of energy. This notion of a "trajectory" does 
not apply to all individuals, as some may not have been sufficiently marked by negative experiences, but it nevertheless helps account for the development of increased alertness in this respect.

In Sébastien's case, like that of most of the people interviewed, his initial habitational experience was acquired in low-quality privately-rented accommodation, and was characterised by uncomfortable extremes of temperature due to the building's poor insulation and heating system. The second stage involves gaining access to higher-quality rented accommodation, whether in the private or government/council housing sector. When government/council accommodation is chosen, accessibility and the availability of shared heating are key criteria.

Alexandra (30, telephone operator, living with a partner) describes how she took careful note of the type of heating when she moved into her apartment: she was absolutely set against having an electric system, and saw shared gas-fired heating as far preferable. Her main concern, however, was not so much the bills - she cannot recall off-hand what her heating costs are - as a certain notion of comfort and a desire for reliability which stems from her past experiences. In her previous rented accommodation she had found herself without any heating and was keen not to repeat the experience: "We'd had a real nightmare with the hot-water tank in our last apartment, and with the heating as well... we even ended up taking the rental agency to court because they didn't want to do anything about it. We had no heating. [...] So I... I did look to see if the boiler was fairly new. [...] I was pleased to see that it was a shared gas-fired system with big cast-iron radiators, as you can see, they're really nice."

With shared heating, energy bills tend to become less visible, disappearing among the other items in the monthly charges. Boudjemaa (37, telephone operator, married, 2 children) rents a council flat with shared gas-fired heating. When he was looking for accommodation, his priority had been to find a council property, as this would allow him to make substantial rent savings compared to the private sector. He even goes so far as to declare that his heating is free, before correcting himself: "Well, you can say it's free. Well, we do pay... When I say free, I mean it's covered by the monthly charges". This lack of attention is reflected in an inability to distinguish the heating bill from amongst the other monthly charges. This "invisibility" of heating costs is in stark contrast to the attention paid to the electricity bill, which is paid separately: "With the electricity, the lights all have low-energy bulbs... [...] We try to run the washing machine at off-peak times, in the evening. It depends, sometimes... I turn off the immersion heater. Because it's electric. In the evenings I turn off the modem, anything to do with the computer, etc. These are just little things, you know. To bring the bill down a bit".

For insulation improvements, tenants have to refer to their landlord. What counts the most in the choice of privately rented accommodation is the type of heating system installed. Concern for the quality of construction is only shown by the wealthiest individuals, along with those who own a car and are thus able to live outside the town centre. This distinction based on access (or not) to a car, whether out of choice or out of inability to afford one, is a determining factor in these accommodation trajectories.

What matters for young people is not so much proximity to their place of work as general accessibility. The markedly unstable character of many career paths makes being located at the centre of a network of transport links more important in their choice of location than enjoying easy access to the job they happen to be in when they are looking for accommodation. For couples living in council/government housing, public transport links were also a major consideration, as those interviewed only had access to one car per household. Therefore, even if only one member of the couple commutes by car, access to public transport remains a decisive factor in choosing where to live. Overall, there was a low level of car ownership among employees living in the town centre, and even when they did have access to a vehicle they tended to use public transport to get to work

While the next step along this trajectory is generally the purchase of an apartment or house, a return to renting may occur in cases of divorce or separation. The need to start living apart rapidly, not to mention cheaply, becomes a priority. Shared custody of children imposes new constraints on location which take priority over all other considerations. Habitational experiences are thus not linear and do not necessarily determine future behaviour. For most people, however, they are a decisive factor. 
Buying a property, in particular a house, thus constitutes the third stage in these accommodation trajectories. Several factors are involved concurrently in the choice of location, including the budget available, car ownership in the household, networks of family and friends, the jobs held by the couple and the proportion of income spent on transport at the time of purchase. Houses are bought on the basis of more or less accurately estimated costs, maintenance and transport costs alike. The choice of heating system and the amount of attention paid to insulation depend to a large extent on previous experiences. Except for those cases when one of the members of the couple has acquired relevant technical knowledge through specialised training, decisions are based on negative past experiences and the information available to the general public. The thermal efficiency of the property and the performance of the heating system depend in these cases on the quality of information available or, for self-builds, on current regulations.

Since people move home less frequently once they have bought a property, budgeting for transport costs, or under-estimating these, can put a long-term strain on finances. A shift in behaviour can be seen to correlate with the date of purchase, namely that the families living furthest from their places of work bought their properties in the 2000s or earlier. This acceptance of travelling large distances was not found in the survey on households' current criteria for buying a property. Rather, those households unable to access housing in their chosen location were unwillingly to buy owing to the recent and apparently permanent rise in the cost of petrol.

The experience related by Adriana (33, administrator, married, 1 child) is typical in that she has had to make various concessions with respect to the distance travelled to work over the course of her accommodation trajectory. She has been working for the same company, currently located $45 \mathrm{~km}$ (29 miles) from her home, for the last 15 years. "[When I started work there] I lived $4 \mathrm{~km}$ [2.5 miles] away. Then I moved to a new place $10 \mathrm{~km}$ [6 miles] away. Then the company moved offices. I was 20 minutes away by car. And then after that I had to buy a place and I had an opportunity to get somewhere cheaper and at the time that added an extra quarter of an hour, you know, a good quarter of an hour." Although Adriana begins by talking in terms of kilometres, it is telling that as the distances increase she begins to measure them in time spent driving, as if this were more acceptable than the number of kilometres covered. Since the traffic on her journey to Pusignan is becoming heavier and heavier, it now takes her 50 minutes to get there.

Company relocations, an element over which couples have no control, retrospectively re-shuffle the cards as far as the latter's choice of where to live is concerned. Catherine (40, married, 2 children) has been working as a transit agent in a logistics firm since 1997. When she started, she was living with her partner in a two-bedroom apartment in Feyzin, southern Lyon. In 2001, shortly after the birth of their first child, the couple had a house built in the city's eastern suburbs, in Saint-Just-Chaleyssin, around $30 \mathrm{~km}$ (20 miles) from her place of work at that time (Genas, south-east of Lyon). Shortly afterwards, Catherine's firm relocated to a site a further five kilometres (3 miles) away, in Pusignan. At the time, her partner was working in Saint-Quentin-Fallavier, less than $15 \mathrm{~km}$ (9 miles) from their house; he later changed company and began working in Corbas, $20 \mathrm{~km}$ (12 miles) from Saint-JustChaleyssin. Successive adjustments of this kind are typical of these constantly evolving trajectories. Economic instability is thus combined with professional instability, exacerbating increases in transport costs.

\section{Mobility}

Like the routines governing energy use in the home, habits of mobility are learnt in the context of the family [22]. For most of our interviewees, even the youngest, getting their driving licence and then a car are part of a process from which it is difficult to escape. Cars are consumer items which, as they wear out, are replaced by older generations, who then pass on any surplus vehicles to younger relatives. This gift of a first car is often what causes driving habits to develop on a family-based model [23]. Our study 
shows that the location of the place of work has a powerful impact on the mode of transport chosen by employees, even among those who had consciously decided that they did not want to drive. The amount of time spent on buses ends up overcoming the willpower of most employees. Julien (31, manager, living with a partner) would have preferred not to have a car. When he first came to Lyon, he found a job on the city's outskirts, on a site not served by public transport. At first, he tried to travel to work using environmentally-friendly methods: "I had to take the metro [underground], then the bus and after that, because the place where I was working didn't have a stop, I had to resort to using a kick scooter, so I bought myself a scooter; in the depths of winter, 20 minutes on a scooter! Morning and evening. In the evening... that meant I was spending two and a half, three hours getting to work each day. That's quite a long time." Very quickly, he decided to buy a small car, with good fuel economy, a Renault 'Twingo Orange'. Julien justifies his purchase by his desire to respect his ecological principles as far as possible.

The other major trigger for the purchase of a car is the birth of children. Once bought, the car is used by the member of the couple with the longest commute. As Boudjemaa (37, telephone operator, married, 2 children) relates: "The twins were born premature. One time it happened that they were both ill and we didn't have a car and so we said to ourselves: "and what if they got ill in the evening...?" The amazing thing was, as soon as we got the car, a week later, they got ill! And that's when I realised that you can't do without it, you really can't do without it. No way. When you're living on your own, well... you can get by, you can muddle through." Having a car is reassuring, and it gives the owner the ability to help others. Owning a car justifies using it for other purposes, such as travelling between home and work, a journey which Boudjemaa had previously tolerated despite the considerable difficulties it presented: "I had to take the tram, the metro, line A and line D, then the bus... you just had to have a problem on one line... and your whole journey would be messed up... It meant that if I was starting work at 8.00, the bus would be there at 7.30 sharp. It would leave at 7.30. That meant that if I turned up at 7.31, I'd have to wait until 8.00. So there's no... all it took was some technical problem on the metro. That happened a lot, metro, technical problem, five minutes late, that's it! I'm not five minutes late, but half an hour late..." A car, then, may be used for purposes other than that for which it was originally purchased. The demonstrable amount of time saved on the journey to work and the ease of day-to-day driving in peri-urban zones are both elements which encourage the daily use of a vehicle.

Two major groups are identifiable among public transport users according to their transport practice and their socio-professional status, broadly reflecting the split between those who have access to a car and those who do not.

The mode of practice exhibited by those whose journey is direct and do not live far from a bus route may be characterised as "unproblematic". They have completed at least two years of study after the baccalauréat (A-Level), are for the most part single and are able to live where they choose. They take the bus even when they own a car, as much for ecological reasons as for reasons of economy and convenience. This practice is the opposite of what we will term the "ordeal by bus" experienced by Julien and Boudjemaa. The latter are employees on short-term contracts living in those urban districts that are least well served by public transport. This group works non-standard hours early in the morning and late in the evening, as well as at weekends, outside normal service times. Most of them also work shifts, which reduces their ability to adapt their routine. While the former group take an average of three quarters of an hour to get to their place of work, the average for these employees is more like an hour and a half. This "ordeal by bus" thus equates to a doubling of journey times in comparison to how long they would take by car, coupled with a likely lack of punctuality owing to the many changes required which has further repercussions on their work.

Car-sharing is one possible solution, in particular for those who work shifts. The call centre based in an industrial estate north of Lyon is, out of the companies surveyed, the one which has best implemented a system of car-sharing in order to make up for the shortcomings of the public transport service. The company works day and evening shifts. The employees on fixed-term contracts are young, are either still studying or are recent graduates, and are single without children. The car-share system is also open 
to permanent staff who live a long way from the site, and is presented to potential recruits at their job interviews as a solution to the problem of getting to and from the site outside normal hours of service. However, the system is based on employees "sorting things out" between themselves, as the company does nothing to organise and facilitate this. Those car owners who live in the city centre are for the most part former public transport users who are well aware of the difficulties involved and are thus happy to offer their services. Nevertheless, car-sharing to and from the city centre is a non-reciprocal service which leads to an imbalanced exchange. The situation makes passengers feel awkward on account of its unilateral character. While the solidarity among employees that the employers rely upon does exist, the situation is nonetheless a rather delicate one for staff who do not own cars, as the system is based on "muddling through" and goodwill, and there are no clearly defined rules regarding remuneration. Journeys to and from work are also subject to various work- and family-related needs and constraints, making car-sharing on a daily basis difficult when the individuals involved do not work the same hours or do not even know which hours they will be working. Car-sharing means having to adapt to the needs of others and, if one of the parties has children, being able to rely on the availability of a partner. It also relies on companies being ready to play their part by ensuring that employees' working hours coincide wherever possible.

\section{Adapting to rising costs}

The survey was conducted in 2012, following several years of consecutive rises in energy prices across the board. Our aim was to establish how households were dealing with this, what changes were occurring in their routines, and what sort of trade-offs were being made between savings achievable within the home and savings on transport costs. The first adjustment made by all these households within the family home was to turn the thermostat down in all or some of the rooms. All homeowners, regardless of their social status and income, as well as when their house was built, had lowered the average temperature in their homes. It is rare that a desire to save money is the only reason given to justify this reduction. Heating in bedrooms may be turned off for the sake of comfort and healthy living, while the thermostat is turned down in the daytime so as not to waste energy. In all these cases, this change in behaviour had occurred over the five years preceding the interview, which is to say since the major rise in fuel prices in 2008. Turning down the thermostat has an immediate effect on the heating bill and does not require making any investment. Its downside is a reduction in comfort and an increased dependence on the vagaries of the weather.

After turning down the thermostat, the second step is to look for alternative, cheaper heating solutions. For those living in houses, this consists in installing a wood-burning stove, the purchase of which had either been made or was being planned for when the interview was conducted. Improving the building's insulation was rarer because of the cost involved. While installing double glazing was considered desirable by most of the homeowners who had not already invested in it, insulating the loft and walls remained less of a priority and only interested those who had the financial means required. It tends to be carried out either when the work is covered by a grant, or at key stages in the individual's life-cycle, such as retirement.

For most homeowners, adapting to the rise in costs does not reflect a pre-planned strategy. Homeowners react on an ad hoc basis as needs and problems arise and force decisions to be taken, or as a reaction to rising costs, with no really concerted attempt to optimise efficiency. Their decisions have a rather improvisatory character, and as a result they come to the conclusion that, despite all the efforts and investments they have made, the rise in costs canot be reversed. Hubert (46, manager, 2 children): "We changed the windows so we "shed" so to speak half a tank [of fuel oil] a year. But what we saved relatively quickly, well it was... It got eaten up as the litre went up, you know. The price per litre". This whole set of behaviours does little to change established habits and does not demand any major changes in the same way that, for example, changes in habits related to transport might do. 
While the costs of commuting tend to be calculated very precisely, indicating greater awareness and concern in the face of rising prices, for the moment this has had relatively little impact on individual habits and lifestyle choices. One indication of change and of increasing tension with respect to energy costs, however, is that employees are actively involved in car-sharing for leisure activities, especially where transporting children is concerned, an area where this practice is preferred whenever possible. Strategies have also been implemented in order to bring down the costs of journeys. When looking for a new car, most people now choose a vehicle with lower fuel consumption. Those who do not do so generally lack the financial means to invest in an energy-efficient vehicle. Toll motorways are avoided as far as possible and average speeds reduced. Finally, whereas the commute from home to work has so far not been seriously affected by the rise in energy costs, households say that are paying more attention to expenditure in other areas, such as leisure activities and food.

\section{Conclusion}

Adaptation to the rise in energy costs is largely being carried out by trial and error on an ad hoc, dayto-day basis. It relies on the application of old-fashioned family values and routines acquired during childhood, along with knowledge gleaned from the media, colleagues and friends. This often patchy knowledge base is called upon as opportunities and/or tensions arise surrounding the family budget, although for the time being this does not involve housing choices being called into question, whether in a peri-urban or urban context. In the report they produced for the CREDOC, B. Maresca et al. [24] have noted, on the basis of surveys conducted before and after the first oil crisis in 1973, that whereas before the crisis interviewees said that they would be prepared to invest in order to lower their energy consumption, in reality this translated into $63 \%$ of interviewees turning down the heating in the homes, a short-term response to an abrupt price change that was reversed as soon as the oil price went down again. The situation today, however, is different in that a range of indicators are leading even the least wellinformed households to conclude that energy prices are not going to drop significantly. The as yet limited development of shuttle bus services for commuting workers is evidence of the difficulties involved in changing these practices, which is not to say that this area of expenditure is not under pressure, as shown by the savings sought in other sectors of family budgets, nor that employees would not be prepared to modify their behaviour, and in particular to car-share, if real opportunities for this were opened up, such as through the reorganisation of working hours within companies or the improvement of on-site amenities.

\section{References}

[1] I. Garabuau-Moussaoui, « Chapitre 3 - L'énergie est-elle un enjeu de pouvoir dans la famille ?», in Barrey S. and Kessous E., Consommer et protéger l'environnement. Convergence ou divergence? pp. 67-89 (Paris, L'Harmattan, 2011a)

[2] X. Desjardins, L. Mettelal, L'habiter périurbain face à l'enjeu énergétique, Flux, pp.46-57, 3, 89-90 (2012)

[3] M. Berger, Les périurbains de Paris. De la ville dense à la métropole éclatée ? (Paris, CNRS eds, 2004)

[4] M. Cartier, I. Coutant, O. Masclet, Y. Siblot, La France des "petits-moyens ». Enquête sur la banlieue pavillonnaire (Paris, Eds de La Découverte, 2008)

[5] J. Mishi, N. Renahy, 2008, « Pour une sociologie politique des mondes ruraux », Politix, pp. 9-21, 21, 83, (2008)

[6] A. Bihr, R. Pfefferkorn, « Le renouveau d'une société de classes »in Bouffartigue P., Le retour des classes sociales. Inégalités, dominations, conflits, pp. 55-71 (Paris, La dispute, Etat des lieux, 2004) 


\section{SHS Web of Conferences}

[7] J.-P. Bozonnet, « Socialisation et engagement écologiste en Europe. L'école, la famille et l'environnementalisme en héritage », Congrès de l'AISLF - Istanbul, du 6 juillet au 11 juillet (2008)

[8] J.-P. Nicolas J.-P. et al., « Mobilité quotidienne et vulnérabilité des ménages », Revue d'éco. rég. et urb., pp. 19-44, 1 (2012)

[9] ibidem

[10] ibidem

[11] E. Shove E., Comfort, Cleanliness and Convenience : The Social Organization of Normality, Oxford-New-York, Berg (2003)

[12] H. Subrémon, « Le climat du chez-soi. Une fabrication saisonnière », Ethno. Fran., pp. 707-714, XL 4 (2010)

[13] I. Garabuau-Moussaoui (2011a) ibidem

[14] J.-P. Bozonnet, ibidem

[15] K. Ilmonen, "Sociology, consumption and routine", in Gronow J., Warde A. (eds), Ordinary Consumption, pp. 9-23 (London, Routledge, 2013)

[16] B. Ehn, O. Löfgren, The Secret World of Doing Nothing (Berkeley, U. of Cal. Press, 2010)

[17] K. Ilmonen, ibidem

[18] I. Garabuau-Moussaoui (2011a) ibidem et I. Garabuau-Moussaoui, "Energy-related logics of action throughout the ages in France: historical milestones, stages of life and intergenerational transmissions”, Energy Efficiency, pp. 493-509, 4 (2011b)

[19] J.-P. Bozonnet, ibidem

[20] I. Garabuau-Moussaoui (2011a, b) ibidem

[21] I. Garabuau-Moussaoui (2011a, b) ibidem

[22] S. Vincent-Geslin, Altermobilités, mode d'emploi. Déterminants et usages de mobilités alternatives au tout voiture, (Lyon, Eds du CERTU, 2010)

[23] A. Rocci, De l'automobilité à la multimodalité ? Analyse sociologique des freins et leviers au changement de comportements vers une réduction de l'usage de la voiture, doctoral thesis, Université de Paris 5 (2007)

[24] B. Maresca, A. Dujin, R. Picard, La consommation d'énergie dans l'habitat entre recherche de confort et impératif écologique, CREDOC, Cahier de recherche, 264 (2009) 